\title{
DIGITAL COMPETENCES OF TEACHERS AND ASSOCIATES AT HIGHER EDUCATIONAL INSTITUTIONS IN THE REPUBLIC OF CROATIA
}

\section{DIGITALNE KOMPETENCIJE UČITELJA I SURADNIKA NA VISOKIM OBRAZOVNIM USTANOVAMA REPUBLIKE HRVATSKE}

\author{
Mirela Müller, Melita Aleksa Varga \\ Department for Pedagogy, Faculty of Humanities and Social Sciences, Osijek, Croatia \\ Odsjek za pedagogiju, Filozofski fakultet, Osijek, Hrvatska
}

\section{Abstract}

One of the basic competences for lifelong learning is the development of digital competence, and especially at higher education institutions. There are long-term goals in economic and social progress in form of initiatives related to the ensuring the multiple information education. Due to the fact that there is not sufficient research aimed at assessing the initial state of information literacy within higher education institutions in Croatia, the goal of the present research is to determine the level of knowledge, more precisely the digital competence of teachers and educators in higher education institutions in the Republic of Croatia, the frequency of their usage of modern technologies in teaching, and to explain the necessity of implementing the multimedia and elearning traning programmes at different faculties. The research was conducted on a representative sample $(\mathrm{N}=1800)$ of teachers and associates at higher education institutions in the Republic of Croatia working in different departments in Osijek, Split and Zagreb. An online questionnaire was used to examine the level of their digital competence, and the frequency and the method of using modern technologies in teaching. The results of the research show that teachers and associates working at technical faculties are more competent in conducting their research scientific

\section{Sažetak}

Jedna od osnovnih kompetencija za cjeloživotno učenje je razvoj digitalne kompetencije, posebno na visokoškolskim ustanovama. Postoje dugoročni ciljevi ekonomskog i društvenog napretka u obliku inicijativa koje se odnose na osiguranje višestrukog informacijskog obrazovanja. S obzirom na to da u Hrvatskoj nema dovoljno istraživanja usmjerenih na ocjenu početnog stanja informacijske pismenosti unutar visokoškolskih ustanova, cilj je ovog istraživanja utvrditi razinu znanja, točnije digitalnu kompetenciju nastavnika u visokoškolskim ustanovama u Republici Hrvatskoj, učestalost njihove upotrebe suvremenih tehnologija u nastavi i objasniti nužnost provođenja multimedijskih i e-learning programa praćenja na različitim fakultetima. Istraživanje je provedeno na reprezentativnom uzorku $(\mathrm{N}=1800)$ nastavnika i suradnika na visokim učilištima u Republici Hrvatskoj koji rade na različitim odjelima u Osijeku, Splitu i Zagrebu. Internetski upitnik korišten je za ispitivanje razine njihove digitalne kompetencije, učestalosti i načina korištenja suvremenih tehnologija u nastavi. Rezultati istraživanja pokazuju da su nastavnici i suradnici koji rade na tehničkim fakultetima kompetentniji za obavljanje svojih istraživačkih znanstvenih radova i koriste suvremene tehnologije znatno više od nastavnika i suradnika koji rade na području društvenih i humanističkih znanosti. Rezultati 
work and use the modern technologies significantly more than teachers and associates working in the area of social sciences and humanities. The results show that more than $70 \%$ of teachers and associates are assessing themselves as being digitally competent in the use of computers and new technologies, and over $60 \%$ of them regularly use media in their teaching practice.

\section{Introduction}

In a digital society everyone is expected to be digitally literate, and in a wider sense, have a fully developed digital competence. The impact of digital technology is evident in all aspects of human life, as well as in education in which digital technology allows dislocated education and turns every living and working space into a potential classroom. Its incorporation in the modern life of every person indicates that there should be a systematic development of digital competence through the formal educational system, the development of which should be included in non-formal and informal educational programs/1/. Digital technology enters almost all spheres of modern life and leads to radical changes in the way of working, learning, spending leisure time and living in general, in fact, it transforms the life of the 21st century. In order to be able to cope with it, every individual has to posess the new type literacy, the so-called tertiary literacy or multiliteracy. According to Gobo /1/, it was actually influenced by new technologies and encompasses a whole spectrum of different literacies that each individual should embrace for successful participation in the contemporary society of the 21st century. Tyner /3/ discusses various aspects in this sense, namely the existence of a) computer literacy (the basic skills needed for an individual to use a computer), b) network literacy (knowledge of the use of global network of information resources), c) technology literacy (the ability to use the media), d) information literacy (set of skills essential for successful functioning in a contemporary media society), e) media literacy (ability to analyze, evaluate communication and communicate), and f) visual literacy (critical observation skills, ability to analyze messages) /2/.

In the Croatian literature, the notion of media literacy is often identified with the notion of digital competence /3/ and implies, along with Tyner's pokazuju da više od $70 \%$ nastavnika i suradnika ocjenjuje sebe digitalno kompetentnim za korištenje računala i novih tehnologija, a preko $60 \%$ njih redovito koristi medije u svojoj nastavnoj praksi.

analysis, the ability to analyze, evaluate and produce communication, but not to develop a reflexive-critical attitude and the ability to discern information from the manipulative role of the media. The different dimensions of digital competence starting from the cognitive, social, and ethical as well as the pragmatic dimension of action and the usage of the media /2/ are considered not to be the result of simple skills, abilities or knowledge, but rather a complex integration of cognitive processes and dimensions. The ethical dimension for instance relates to the question of what is ethical in the media and what is functional /3/. Due to the misunderstanding of the notion of media literacy and digital competence in syllabi of different teaching courses in Croatia, the aim of the course is very often not connected with its learning outcomes. This presents a major problem in the realization of the teaching process and in the use of different teaching methods. It is precisely for these reasons that at faculties, especially those with teacher training courses, it is necessary to identify which type of technology is being used with which type of teaching method in order to improve the teaching process. Not every teaching method is intended for the same program or application. For these reasons it is important to develop the different dimensions of digital competences, so that teachers can respond to the ever-growing and demanding needs of the digital and information society by possessing the required knowledge, skills and abilities.

\section{Media literacy, digital competence and young generation}

German media psychologists and pedagogues have analyzed six functions of media, namely the 1) communicative, 2) cognitive, 3) socio-political, 4) cultural, 5) educational (transfer of communication among participants in the educational process) and 6) social-humanistic /4/, 
/5/. Students today live in a time where the possibilities of understanding and constituting human freedom are increasing, but it is also the time of "enslaving" the young person; time in which it is possible to lose the identity, the critical and intrinsic values, the needs and (self) respect $/ \mathbf{1} /, / 6 /$. Young people today have more choices, but they are also accompanied by the weak influence of social values and the insensibility due to the rapid development of the technical revolution $/ 7 /$. For young people the fact that they have to integrate into the digital society with lots of opportunities for gathering information could be considered rather problematic $/ 8 /$. Therefore the teachers and associates at higher educational institutions have to provide the necessary link between the new technologies and young people and teach the students to check different media information, warn them more often about evaluating them, making them aware how to use a certain technology in a pragmatic and functional way. Teachers have to strive not to become a e-teachers or ementors because technologies will never be able to replace their role in the direct communication since information makes it possible to create knowledge, but one should not be identified with all types of it /9/. Contemporary media (especially electronic) multiply the amount of information available and the speed of their transmission, but do not guarantee their multiple utility and ethics /8/. In order to obtain knowledge from the accumulated information into the system of logically structured facts and abstractions, it is crucial to develop the skills of critical thinking. Otherwise, there may be a situation in which an individual does not control information, but the other way around- the information is controlled by him /6/. Due to the rapidly accelerating scientific and technological advancement, there is also an accelerated obsolescence of competences in all areas of knowledge, so that the necessity of adopting

\footnotetext{
${ }^{1}$ The aim of the Program is to enable students to acquire new multimedia competences in the process of multimedia training, together with the development of digital literacy, and to enable them to use e-learning in the process of ISSN 1330-0067
}

flexible forms of learning in all areas is emphasized. The concept of "learning" the learning therefore involves actually building a critical approach to information based on the learning of thinking, reviewing, and the ability to adapt quickly /10/. A quality and direct mediation based on dialogue cannot be replaced or suppressed by any other form of digital mediation because the media themselves do not provide desired socialization and upbringing. That is why today we are talking about their ambivalent role and why the results of research showed the necessity of implementing the Multimedia Training and E-Learning programs ${ }^{1}$ at teaching faculties where future teachers are being trained, especially through the introduction of I-Padova in teaching.

\section{Multimedia Training and e-Learning Program in Croatia}

Every contemporary research in Croatia and abroad nowadays points to the necessity of integrating modern technologies in teaching in the context of improving scientific and teaching work at higher educational institutions, especially those that have teacher training courses /3/. If we take a look at foreign universities, we can see that the University of Harvard, MartinLuther University in Wittenberg, Fern University, Heidelberg University, Humboldt and the Johannes Gutenberg University have all been successfully conducting e-learning programmes within various e-learning components at higher educational institutions (Bundesministerium für Hochschulbildung, 2010) /7/. In order to implement similar e-learning programs in Croatia, the teachers should posess a realtively high level of digital competence. Unfortunately, there have not been sufficient studies on the assessment of digital competence of teachers and associates working at higher educational institutions in Croatia. Given the fact that the modern Croatian society is striving for a new educational reform in which information

technical and methodological development, to acquire basic knowledge in the process of multimedia learning of a foreign language. The access to this Program is interdisciplinary.

Coden: IORME7 
technology plays a key role, this creates problematic issues: How should we train future teachers to work with new mass communications if teachers themselves do not have a sufficiently developed digital competence? /11/, $/ 12 /, / 13 /$. The main question that arose from these facts is how teachers and associates nowadays approach technologies and in which form? The premises of the present research are therefore the assessment of digital competence of teachers and associates working at higher educational institutions in Croatia and the possibility of introducing the Multimedia Learning and E-Learning Program. The Program is intended for faculties with teacher training courses, with an aim to enable teachers, future teachers and associates acquire new multimedia competences, to develop the digital literacy and to qualify them for e-learning, as well as to acquire basic knowledge regarding the multimedia learning and foreign languages.

The program would consist of acquiring basic levels of digital competence, and include the following:

- Analysis and implementation of e-learning (application of lifelong learning media, connection of digital communication and media taxonomy with databases, table calculations, distance learning, e-learning programs and tools: programs for acquiring academic titles from sciences, programs for further training, retraining, specialization and programs in the field of culture of life)

- Methodology and didactics in e-learning: Methodological basics of e-learning and methods: a) bleanded learning, b) social searning and Web 3.0 c) mobile learning, d) WebQuests and Game Based Learning

- Didactic basics: a) didactic models of e-learning, didactic web-design in e-learning, c) elearning platforms, d) construction of multimedia systems, e) techniques for using multimedia for learning and developing online materials in web technology on a higher level, starting from ECDL to ECDL CAD (Computer Aided Design) and ECDL CTP (Certified Training Professional), ECDL ImageMaker.

This concept provides a more holistic view of ICT and its inclusion in the information society, establishing a balance between technologically focused and a socially humanistic approach to teaching ${ }^{2}$. Introducing the information and communication technologies in teaching and the development of e-learning is one of the key tasks of the program according to which Multimedia Training and E-Learning would be recognized as a center of excellence at various higher educational institutions in Croatia.

\section{RESEARCH}

\section{The purpose of research and tasks}

The purpose of the present research, as stated above, is to determine the level of digital competences of teachers and associates at higher educational institutions in Croatia. The defined level of digital competence will determine the methods, but also the quantity of implementing the Multimedia Learning and e-Learning Program at the Universities of Osijek, Split and Zagreb as part of the Multimedia Lifelong Learning Program. Certain multimedia didactic exercises in the field of e-learning and education would be conducted at those departments of the Universities where there is a need for it. The results of the present research will be compared with foreign institutions where the research is also being conducted (Germany, France) in due course. The research tasks can be described as follows:

- To determine the level of digital competence of teachers and associates

- To determine the impact of the scientific field and the University where teachers and associates work

- To determine the knowledge and the frequency of application of information and communication technologies in the educational process.

- To identify the key digital competencies of teachers needed for working with new media

\section{Hypotheses}

1. The development of digital competence needed for the improvement of scientific and teaching work and work with students is significantly influenced by the scientific field of teachers and associates.

\footnotetext{
${ }^{2}$ Izgradnja europskog prostora cjeloživotnog učenja, Bruxelles, COM(2001) 678 final
} 
2. The knowledge of new web terminology as well as the more frequent use of modern media in teaching significantly contributes to the assessment of digital competence regarding the communication with students and determining new education paradigms in the syllabi of study programs.

3. The scientific area and the University where the teachers and associates who participated in online research have been employed do not have an impact on the assessment of the competence regarding the application of e-learning technology in teaching.

\section{METHOD}

\section{Respondents}

The present research was conducted on a representative sample $(\mathrm{N}=1800)$ of teachers and associates working at higher educational institutions in the Republic of Croatia at various faculties and departments in Osijek ( $\mathrm{N}=720,40 \%)$, Split $(\mathrm{N}=594,33 \%)$ and Zagreb $=486,27 \%)$ Teachers and associates participating in the research were selected by using a stratified sample method. Out of a total of 1800 respondents, there were 990 female (55\%) and 810 male (45\%) participants. The average age of subjects at the time of the study was 35 to 58 years.

\section{Instruments and measures}

The present study is part of a wider research on determining the level of knowledge of digital competence and the frequency of the use of modern technologies in teaching among higher education teachers and associates in Europe, namely the DFGP project "E-learning and Multimediakompetenz der Deutschen Initiative für Netzwerk Information". The preliminary online research was conducted from April 2, 2015 to June 14, 2015, the survey questionnaire developed by experts (media psychologists) from the University of Johannes Guttenberg Mainz ithin the framework of a joint European project was uploaded to the web pages of individual university components. In the course of this paper only the most important research results related to ICT use in teaching and working with students will be presented. The aim of the first eight questions was to collect general data related to the set variables (gender, university name - component, place of residence, teaching experience, university location, scientific area and vocation). The second part of the online questionnaire consisted of nineteen questions where the respondents assessed their own level of knowledge of digital competence, the frequency of use of modern technology in teaching and their scientific and practical work, the purpose of using ICT in general, a self-assessment of the ways they obtain information through digital sources, and a self-assessment of their own motivation for implementing e- teaching into their own work. The application of the knowledge of digital competences in the scientific and practical work was assessed by a fourstage scale (1 - never, 4 - often). In questions where respondents evaluated the frequency of using new technologies, they responded by choosing from seven options: everyday, several times a day, once a week, several times a month, once a month, less than once a month, I do not use new technology for work and teaching. In questions where they had to chose the level of their agreement with different statements respondents had to click on a five-degree scale, where 1 was standing for I completely disagree, to 5 for I completely agree. In questions related to assessing their own knowledge, respondents could choose among five answers: excellent, very good, good, weak, very poor. All the data were analyzed by using SPSS for Windows, in the course of which measures of descriptive statistics, chisquare $(\chi 2)$ and correlation analysis (Cramer's $\mathrm{V}$ (Qc) coefficient) were used.

\section{RESULTS AND DISCUSSION}

According to the set data, the overall dispersion of respondents regarding their place of employment at the Croatian Universities was as follows:

- University of Osijek (40\%): Faculty of Humanities and Social Sciences, Faculty of Educational Sciences, Faculty of Electrical En- 
gineering, Faculty of Economics, Department of Culture, Faculty of Technology, and Faculty of Law

- University of Zagreb (27\%): Faculty of Humanities and Social Sciences, Faculty of Kinesiology, Faculty of Law, Faculty of Architecture, Faculty of Economics

- University of Split (33\%): Faculty of Humanities and Social Sciences, Faculty of Law, Faculty of Economics, Art Academy, Faculty of Medicine, Faculty of Teacher Education, Faculty of Chemistry and Technology and Faculty of Electrical Engineering.
According to the results of the chi-square test $(\lambda 2)$ there is a statistically significant difference regarding the age $\left(\chi^{2}=32.9, \mathrm{df}=3, \mathrm{p} \leq .01\right)$ and the gender of the respondents $(\chi=36.0, \mathrm{df}=1$, $\mathrm{p} \leq .01)$. There was a siginificantly higher number of partcipants aged 35 to $45(\mathrm{~N}=52.14 \%)$ than those in the age group 55 to $65(\mathrm{~N}=8 \%)$. It can be therefore concluded that respondents aged 35-45 were probably more motivated to take part in the questionnaire and had a higher level of digital competence than respondents aged 55-65.

Table 1. Comparison of the respondents regarding their age, gender and place of residence.

\begin{tabular}{lll}
\hline Gender & Percentage(\%) & $\mathbf{N}$ \\
\hline $\mathrm{M}$ & $45 \%$ & 810 \\
\hline $\mathrm{F}$ & $55 \%$ & 990 \\
\hline Age & & \\
\hline $25-35$ years old & $6 \%$ & 108 \\
\hline $35-45$ years old & $52,1 \%$ & 938 \\
\hline $45-55$ years old & $33,86 \%$ & 610 \\
\hline $55-65$ years old & $8 \%$ & 144 \\
\hline Place of residence & & \\
\hline Gradska sredina & $80,96 \%$ & 1458 \\
\hline Prigradska sredina & $14,02 \%$ & 252 \\
\hline Seoska sredina & $5,02 \%$ & 90 \\
\hline
\end{tabular}

The prevalence of respondents by scientific areas and their occupation is presented in Table 2. Most respondents work in the field of social sciences $(43.69 \%)$, followed by respondents in humanities $(24.39 \%)$ and in the field of technical sciences $(19.89 \%)$. The results show that the most of the respondents were assistant professors $(36.78 \%)$, followed by teaching assistants $(27.56 \%)$ and lecturers / associates
(14.95\%). According to the results of the chisquare test, there was a statistically significant difference among the respondents with respect to the occupation $(\chi 2=112.2, \mathrm{df}=6, \mathrm{p}<.05)$. Repondents bearing the title of assistant professors who participated in research had most probably a higher motivation and a greater digital competence than full professors who participated in the smallest number.

Table 2. Prevalence of respondents according to their occupation and scientific field

\begin{tabular}{cl||l|c}
\hline Occupation & $\begin{array}{l}\text { Preva- } \\
\text { lence (\%) }\end{array}$ & $\begin{array}{l}\text { Scientific } \\
\text { area }\end{array}$ & Prevalence (\%) \\
\hline Lecturer /associate & $14,95 \%$ & $\begin{array}{l}\text { Natural } \\
\text { Sciences }\end{array}$ & $4,5 \%$ \\
\hline Teaching assistant & $27,6 \%$ & $\begin{array}{l}\text { Technical } \\
\text { Sciences }\end{array}$ & $19,89 \%$ \\
\hline Assistant Professor & $36,78 \%$ & $\begin{array}{l}\text { Social Sci- } \\
\text { ences }\end{array}$ & $43,69 \%$ \\
\hline Associate Professor & $10,3 \%$ & $\begin{array}{l}\text { Humani- } \\
\text { ties }\end{array}$ & $34,39 \%$ \\
Professor & $8,2 \%$ & $\begin{array}{l}\text { Biomedi- } \\
\text { cine and } \\
\text { Health }\end{array}$ & $5,53 \%$ \\
\hline
\end{tabular}




\begin{tabular}{ll||c}
\hline Full Professor & $2,1 \%$ & Others \\
\hline Others & $0,11 \%$ & $2 \%$ \\
\hline
\end{tabular}

When it comes to the assessment of the digital competence of the entire sample of the respondents, the chi-square test $(\chi 2=737,32, \mathrm{df}$ $=4, \mathrm{p}<.05)$ showed that there is a siginificant difference. $36.78 \%$ of the respondents assess their digital competence as very good and $35.06 \%$ as excellent. That is, over $70 \%$ of the respondents think they are competent in the use of computers and new technologies (Figure 1). If we analyze the responses of all respondents according to the type of their current occupation, we can see that teaching assistants, lecturers and assistant professors consider that they belong to the so-called digital generation $(65.56 \%)$ and that in the course of their studies (workshops, postgraduate doctoral studies, etc.), they had lectures regarding the ICT technologies related to the development of digital competences. If we compare the results of the respondents working in the position of the associate professor to the full-time professor, we can see that they do not consider they belong to the socalled "digital generation" (34.44\%) because they did not have sufficient training in using the ICT technologies regarding the aspect of distance education. Also, the research showed that $76.35 \%$ of the respondents who claim they belonged to the digital generation had a personal computer, iPad, or any other type of innovative technologies such as e-Book reader, whereas $23.65 \%$ of the respondents who consider themselves as not belonging to the digital generation do not possess such devices. When comparing results from the scientific point of view, the majority of the respondents $(\chi 2=717,32, \mathrm{df}=3, \mathrm{p}<.05)$ belonging to humanities and social sciences, and biomedicine and health consider that they have reached the general level digital competence, which means they posess the knowledge of how to use e.g. Microsoft Office (46.25\%), but do not know how to work with e-tools and software such as Team-View.

Fig. 1. Self-assesment of digital competence

Figure 1.Self-assessment of digital competence

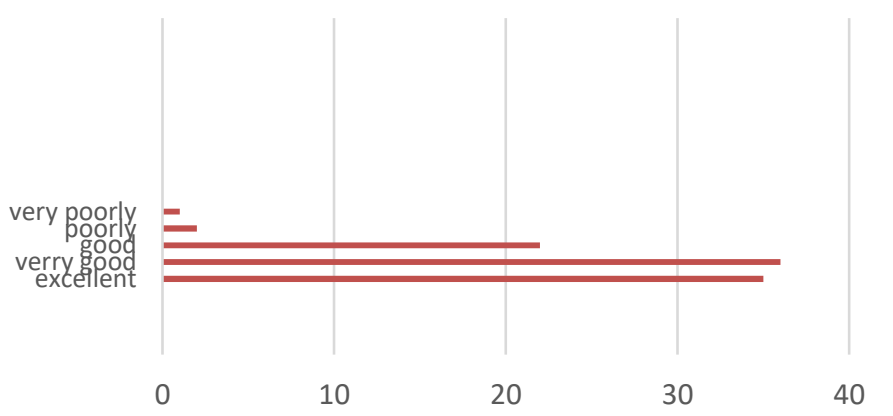

(Legend:1.excellent,2.verry good, 3. good, 4.poorly, 5. very poorly) 
The questions regarding the assessment of knowledge in the field of e-Learning technology used for teaching, like e.g. the MOODLE platform, show that there is a significant difference $(\chi 2=502.85, \mathrm{df}=4, \mathrm{p}<.05)$ regarding scientific fields. The results showed that most repsondents use MOODLE in course of their teaching (Figure 2), but if we analyze the results regarding the scientific field of the participants (Table 3), we can see that respondents who come from the technical $(56.8 \%)$ field of education and the humanities (42.5\%) use MOODLE more frequently in their teaching than respondents working in the field od social sciences (39.6\%). There was also a statistically significant difference and a slight correlation between the respondents working in the field of technical sciences of the University of Split and the University of Osijek regarding the use of MOODLE platform in teaching $(\chi 2=139.12, \mathrm{df}=2, \mathrm{p}<0.05$, Cramers V = .19).

Table 3. Assesment ot the frequency of usage of MOODLE platform in teaching regarding the scientific field of teachers and associates on Croatian universities

\begin{tabular}{|c|c|c|c|c|}
\hline Scientific area & $\begin{array}{l}\text { Preva- } \\
\text { lence } \\
\text { total } \\
(\%) \\
\end{array}$ & Split (\%) & $\begin{array}{l}\text { Zagreb } \\
(\%)\end{array}$ & $\begin{array}{l}\text { Osijek } \\
(\%)\end{array}$ \\
\hline $\begin{array}{ll}\text { Natural Sci- } \\
\text { ences }\end{array}$ & 24,51 & 26,53 & 20,31 & 28,65 \\
\hline $\begin{array}{l}\text { Technical Sci- } \\
\text { ences }\end{array}$ & 56,8 & 18,65 & 4,56 & 19,99 \\
\hline Social Sciences & 39,6 & 21,36 & 14,79 & 24,25 \\
\hline Humanities & 42,5 & 22,36 & 11,49 & 23,65 \\
\hline $\begin{array}{l}\text { Biomedicine } \\
\text { and Health }\end{array}$ & 13,4 & 21,56 & 11,79 & 23,25 \\
\hline Others & 1,6 & 36,56 & 19,95 & 41,89 \\
\hline
\end{tabular}

Figure 2. Self-assessment of knowledge in the field of application of e-Learning technology in teaching (e.g. MOODLE platform);

Figure 2. Self-assessment of knowledge in the field of application of eLearning technology in teaching (e.g. MOODLE platform);

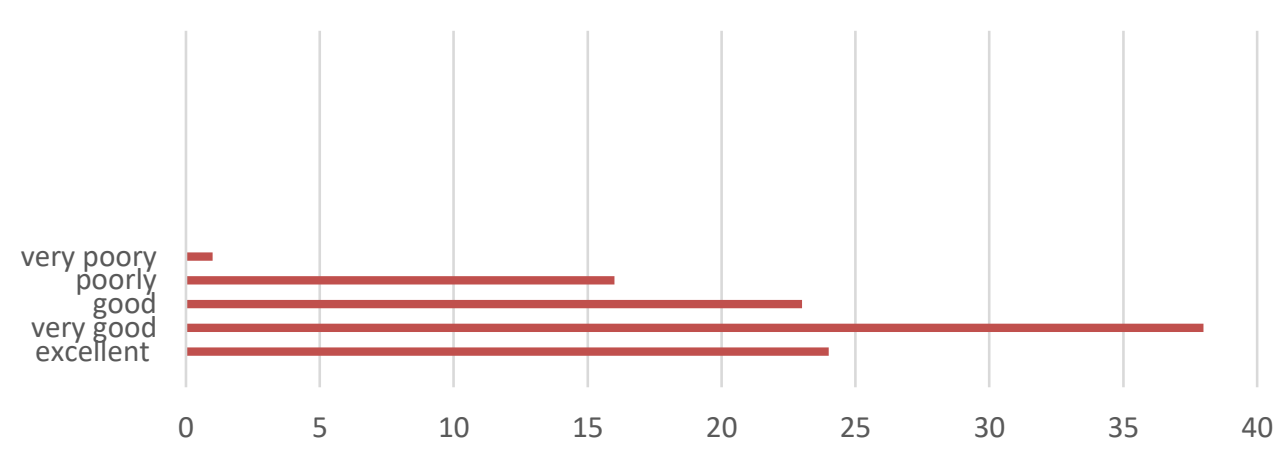

(Legend:1.excellent,2.verry good, 3. good, 4.poorly, 5. very poorly) 
These results are expected since teachers working in the field of technical sciences use digital technologies more than teachers working in the field of social sciences. Inspired by different recent researches that point to the necessity of integrating modern technologies in teaching in the context of improving the scientific work and the teaching at higher educational institutions, we can see from this study that this integration certainly should most certainly include teachers and students in social sciences working and studying in Croatia.
The results of the survey showed that respondents are mostly familiar with web-based terms such as multimedia (67.56\%), mobile communications (99.68\%), and Wikipedia (57.59\%). There was a significant correlation observed between the respondents from technical science and humanities regarding other web-based terminology $(\mathrm{r}=.41, \mathrm{p} \leq .05)$ compared to respondents working in social sciences (Table 4 ).

Table 4. Estimating the knowledge of web-based terminology regarding the scientific area of teachers and associates;

\begin{tabular}{|c|c|c|c|c|c|c|}
\hline Web-based term & $\begin{array}{l}\text { Prevalence total } \\
\text { (\%) }\end{array}$ & $\begin{array}{l}\text { Natural Sci- } \\
\text { ences } \\
(\%)\end{array}$ & $\begin{array}{l}\text { Technical } \\
\text { Sciences } \\
(\%)\end{array}$ & $\begin{array}{l}\begin{array}{l}\text { Social Sci- } \\
\text { ences }\end{array} \\
(\%)\end{array}$ & $\begin{array}{l}\text { Humanities } \\
\text { (\%) }\end{array}$ & $\begin{array}{l}\text { Biomedicine } \\
\text { and Health } \\
(\%)\end{array}$ \\
\hline Hypertext & $78,84 \%$ & 12,11 & 27,56 & 13,44 & 23,78 & 1,95 \\
\hline Hypermedia & $83,45 \%$ & 11,11 & 26,23 & 12,45 & 24,45 & 9,21 \\
\hline Multimedia & $67,56 \%$ & 9,45 & 22,12 & 11,23 & 23,23 & 1,53 \\
\hline Instant Messaging & $23,64 \%$ & 4,53 & 6,23 & 2,23 & 5,42 & 5,25 \\
\hline WEB 2.0 & $98,78 \%$ & 13,45 & 31,45 & 9,45 & 22,87 & 21,56 \\
\hline Dokuwiki & $26,36 \%$ & 0,45 & 11,84 & 2,36 & 7,26 & 4,45 \\
\hline $\begin{array}{l}\text { Mobile Instant } \\
\text { Messaging } \\
\text { grams }\end{array}$ & $99,86 \%$ & 3,56 & 78,56 & 2,23 & 9,46 & 6,35 \\
\hline Wikipedia & $57,59 \%$ & 7,89 & 21,56 & 6,54 & 9,96 & 11,64 \\
\hline Wikianswers & $35,65 \%$ & 2,12 & 21,23 & 1,23 & 13,36 & 0,17 \\
\hline Wikiversity & $25,56 \%$ & 0,36 & 16,36 & 0,12 & 2,36 & 6,36 \\
\hline YackPack & $14,65 \%$ & 0,11 & 11,36 & 0,23 & 1,23 & 1,72 \\
\hline Slidestory & $9,36 \%$ & 1,11 & 7,36 & 0,12 & 0,65 & 0,12 \\
\hline $\begin{array}{l}\text { Google Docs \& } \\
\text { Spreadsheets }\end{array}$ & $68,87 \%$ & 4,23 & 58,59 & 1,11 & 3,26 & 1,38 \\
\hline
\end{tabular}

Comparing the assessment of the importance of digital compentence for teachers in order to work with new media, respondents agree that most of these skills are necessary for their work in the teaching process (Figure 3), apart from the use of social networks. Respondents do not ISSN 1330-0067 estimate those as a key competence alongside with organizating the work on a PC. Therefore, most respondents in the assessment of key digital competences fully agree that for their work with students and their scientific work the most important skills are the knowledge of working Coden: IORME7 
with various computer programs such as Office, the use of the Internet, the competence to write, read and understands texts coming from digital sources, send and receive e-mails, analyze and evaluate e-information. What most of the respondents find less important regarding the key digital competence is the database search and identifying the digital sources. This is actually quite worrying because the database search should be of great importance for their scientific work, and necessary for their progress in science and research.

Figure 3. Assesment of key digital competences of teachers working with new media

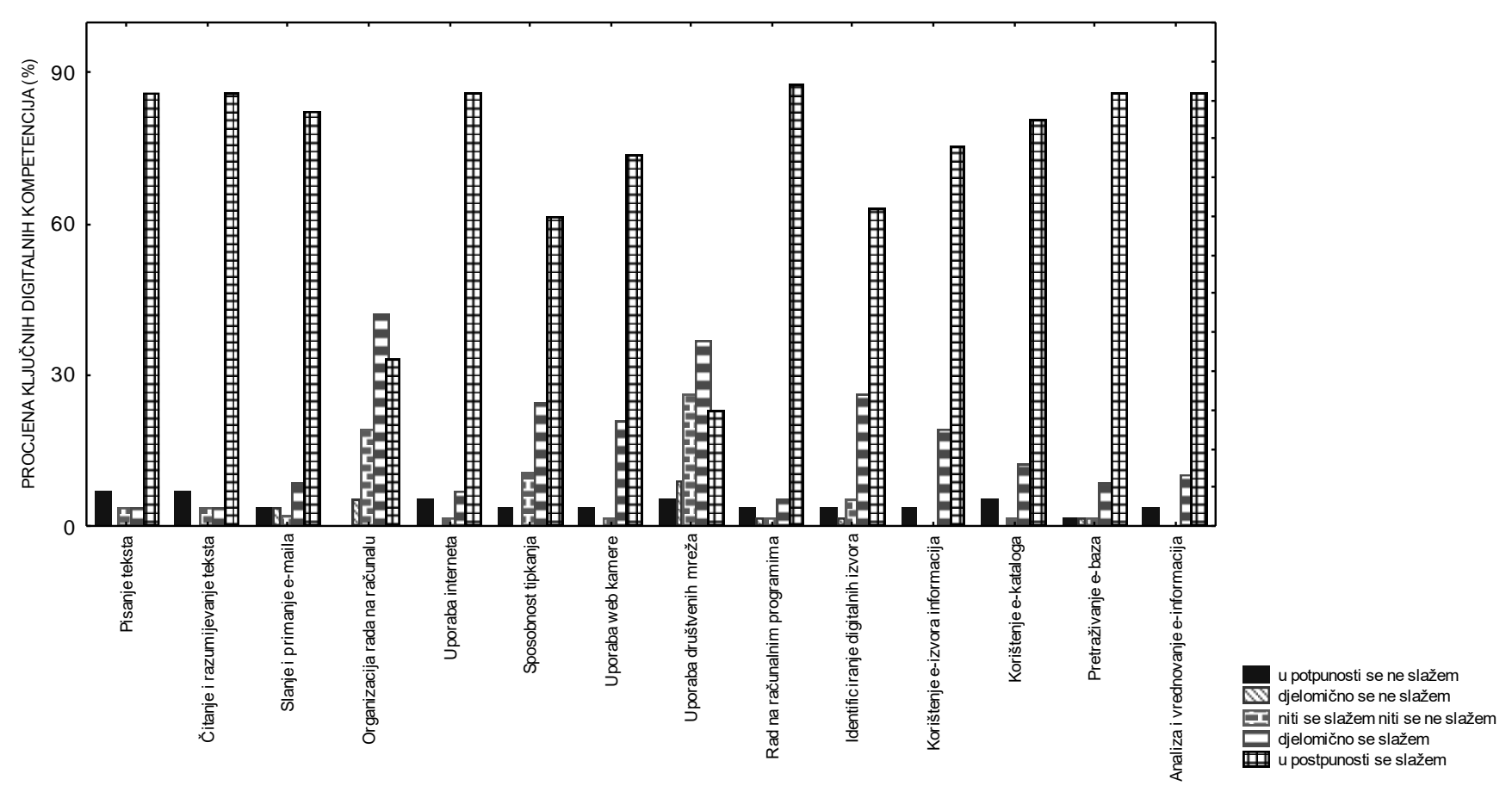


Another aspect of the present research is the assement of digital competence needed for the work with new media in the teaching process. As we have already ecountered, the change of globalization caused by the new media has an ambivalent role. With the development of new media, there is a growing need for the development of media culture, especially in the process of education. Media users (pupils, teachers and/or parents) can potentially decide for themselves whether or not they need a product and for what purpose. Media defines a relationship in which the identity is shaped by the symbolic "game" of cultural factors. It contains preferences that media consumers connect with their own interests. The symbolic aspects of imposed demands in advertisements in which (exotic) images of wishes, beauty and success are presented are being highlighted. Advertisements, information and entertainment, fiction and the construction of reality is actually mingled with aesthetics and everyday culture. Offers from media are formally and substantially becoming equal to actual human needs. The media manipulation box opens here $/ \mathbf{1 4} /$, which is an important aspect in acquiring media competence. The questions that arise at this point are: What are the consequences regarding children and young people if they uncritically use the social and new media? Will they be aware of the dangers of manipulation and losing their own identity? The key question would actually be who and what are the uses of different media /15/? In the course of the present research the results of the chi-square test show a statistically significant difference in the estimation of the frequency of using the new media in teaching ( $\chi 2$ $=990,58, \mathrm{df}=3, \mathrm{p}<.05)$. Respondents stated in more than $60 \%$ of cases that they always use the media in their own teaching process while $2 \%$ never uses them (Figure 4). The assessment of key digital competence also corroborated the statistical data. The higher the level of the adopted digital competences is, the greater the possibility is of using the media in the teaching process.

Figure 4. Frequency of the usage of new media in the teaching process

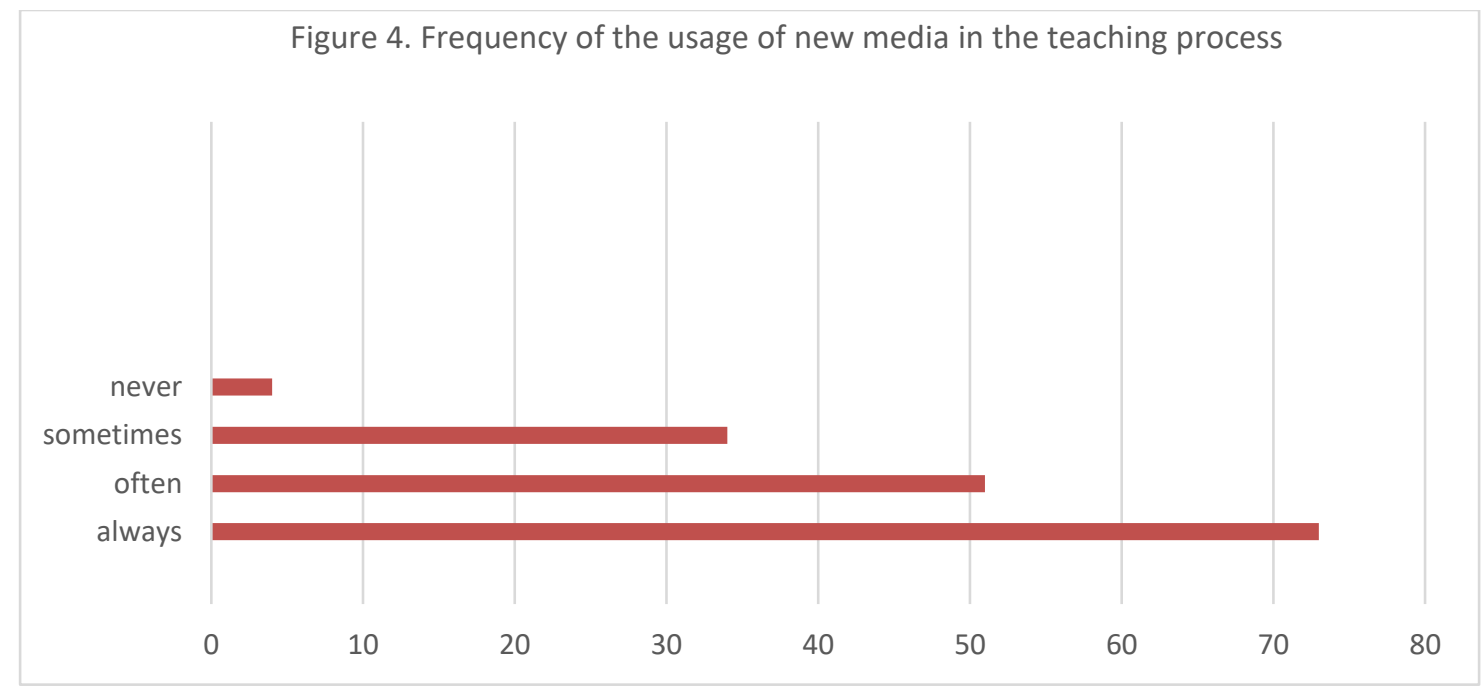

(Legend:1.alwyas,2.often, 3. Sometimes, 4. Never) 
Figure 4 presents the assessment of the purpose of using media in the teaching process. $73.2 \%$ of the respondents stated that they mostly use modern technologies in presenting the results and assignments, $66,1 \%$ uses them in facilitating methodical changes in teaching, $63,6 \%$ in creating creative tasks, $62,5 \%$ for improving learning outcomes, $61,8 \%$ for the transmission of up-to-date information. $60,7 \%$ of the respondents stated that they use modern technologies in promoting work creativity, $60,7 \%$ use it for better communication among colleagues and students and $53,6 \%$ as an implication of a new learning environment, $46,4 \%$ for enabling the evaluation of learning. The majority of the respondents state that the purpose of using modern technologies in teaching is to improve the way they work according to EU standards, ie the recommendations of the White Document and the Strategy for Planning the Higher Education until $2030^{3}$.

Figure 5. Assessment of the usage of modern media in the teaching process

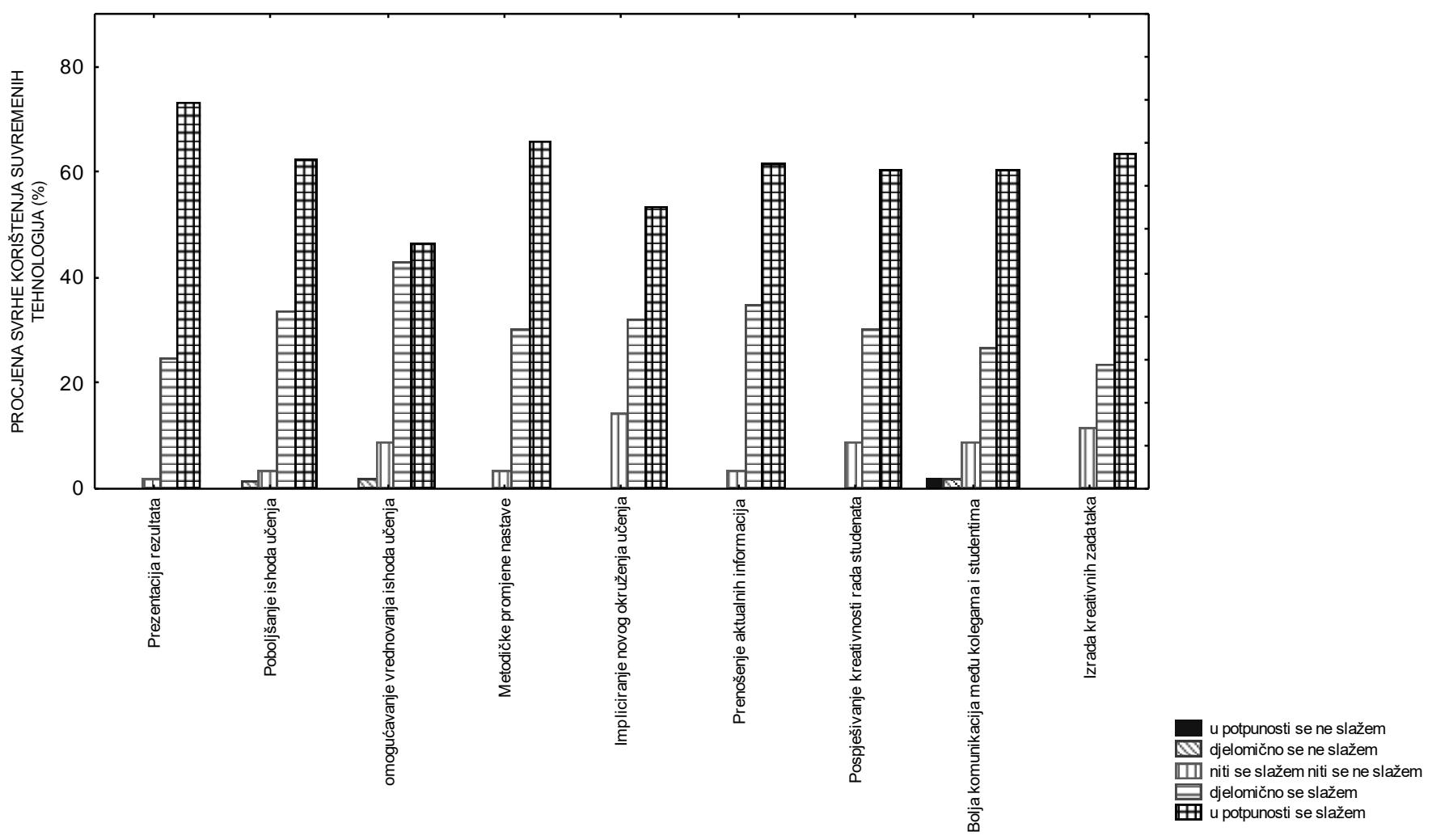

${ }^{3}$ http://eur-lex.europa.eu/legal-

content/HR/TXT/?uri=CELEX:52013AE5751 
In examining the connection between the agreement with different statements and the frequency of the use of technology in the teaching, a correlation analysis and separate $\chi 2$ tests were made. In the table below (Table 4), we can observe high correlation $(\mathrm{r}=.78)$ between the statement that media has an ambivalent role in the process of education (statement 2) with the item stating that media improve the learning outcomes. In other words, those respondents who believe that media has an ambivalent role mostly use the media for improving the learning outcomes. There was also a high correlation $(\mathrm{r}=.74)$ accounted regarding the statement that future teachers should be trained to work with new media (statement 8) and the purpose of using modern technologies for creative work. In other words, respondents who believe that students should be trained to work with new media most often use the media for different creative tasks.

Table 5. Relationship between the agreement of statements and the purpose and frequency of using technology in the teaching process

$\begin{array}{lll}\text { Statements } \quad \text { Correlation } \quad \text { Chi-square } & \begin{array}{l}\text { Purpose and frequency of using technol- } \\ \text { ogy in the teaching process }\end{array}\end{array}$

1. Media are social bearers of the young generation

2. Media has an abivalent role in the process of education

.787852

$$
5,911, \mathrm{p} \leq .05
$$

2. to enhance the learning outcomes

3. to evaluate the learning outcomes

3. new media in the teaching should be topicalized

$$
3,251, \mathrm{p} \leq .05
$$

4. to implicate new learning environment

4. colleagues at work should know how to handle new technologies

5. new media does not belong to the classroom

6. new media should be meaningfully used

7. teachers should be taught to work with new media

.436512
$4,951, \mathrm{p} \leq 0.05$

5. to transmit actual information

$$
4,521, \mathrm{p} \leq .05
$$

6. to enhance creativity in working with students

7. for better communication between colleagues and students

8. for creative tasks 
8. students should be taught to work with new media

$3,5, \mathrm{p} \leq .05$

9. discuss in class about the influence of media on the mindset and behavior of students

.741232

$6,251, p \leq .05$

10. to didactically use new media in order to make the teaching process more successful

11. to develop the students' digital competence
$.234152 \quad 4,131, \mathrm{p} \leq .05$

11. music, CD-player, audio player, audio data

12. computer, text processing, tables, internet search, online tasks, webinars
.321232

.512365

\section{Conclusion}

The opinions of teachers and associates who work at higher educational institutions show that technical sciences are at the forefront compared to social sciences and humanities. However, respondents coming from the field of humanities use more often technology in teaching students and for their own scientific work, which is also being corroborated by the significant correlation regarding the greater familiarity with web terminology of respondents coming from the field of technical sciences and humanities compared to social sciences. Respondents working in the field of social sciences claim that they have not been encouraged to use Moodle in their teaching and are less familiar with new web terminology, which makes it clear that further professional training for people working in this area is absolutely necessary. All respondents agree with the statement that they still do not sufficiently assess their online work and their achievement in their scientific research. From the perspective of the National Council for Science and Higher Education, respondents generally agree with the fact that new paradigms of education should be defined in the learning outcomes of the syllabi and linked with multimedia teaching and learning. New paradigms should focus on developing key levels of digital competence not only for teachers and associates but also for students, as is already stated in the afore mentioned Multimedia Training and E-Learning Program. In this context, the following key digital competencies should be developed with the following goals regarding teachers and associates:

a) they should be trained in acquiring basic computer knowledge, how to use digital technology, disseminate the notion of information literacy and to understand data, information and integrate them, 
b) they should be able to use multimedia and all of the features in the MS Office pack (MS Word, Excel, PPT, Outlook);

c) they should be able to creatively and safely use mobile networks and applications and critically evaluate different digital information sources;

d) they should understand the main computer applications and know how to apply the technologies of the information society to creativity support the personal fulfillment, inclusion in the society and their own employment;

e) they should be able to search, collect and process information and data;

f) they should be able to use presentations, charts, diagrams;

g) they should be able to independently design an educational program in an online environment for the purpose of online teaching;

h) they should didactically form the web media;

i) they should know how to apply the concept of e-learning (XMOOCs: video conferencing, CMOOCs: webinars, LMS platform, Open Access, Open Content, Blended Learning, SCORUM, Virtual Classroom, Web Based Training, Open Source Software);

(j) they should know how to use the tools and systems that allow storaging the content on serverers and use online questionnaires in Docs;

k) the should understand the need for lifelong learning, individual initiatives and personal development, and use the digital potentials for the purpose of improving economic resources;

1) they should know how to make a MOCCS system in a SPOC (Harvard Model) system where online courses can be formed up to a maximum of 500 participants according to different modules to improve their company or institution; m) they should institutions or companies with TeamViewer software to improve work, income, develop professionally and economically

n) they should use computer data in order to create business graphics;

o) they should conduct scientific research marketing activities through social media and create user documentation, design information systems with an understanding of ontology of web media (knowledge, skills and abilities).

Media education in schools should have three main aspects:

1. Using media for different tasks. The goal is to account for different media and create the ability to critically select and evaluate information $/ 15 /$.

2. Insight into the mode of operation and the conditions of the different media. Open questions that have been ignored, such as the issue of personal taste, preferences and pleasures, are becoming increasingly important in pedagogical work /12/. Young people should be familiar with different types of programs (eg magazines for teenagers, soaps operas, etc.), and with different presentation forms, as prerequisites for proper action /16/. Critical analysis requires knowledge of the conditions of media production, distribution and access to editorial policies $/ 17 /$.

3. Practical and creative media work. The aim of this is to expand the possibilities of expression and creative work that build the ability to accurate perceive and behave socially responsible regarding media and media users. By participating in creating school magazines, photography exhibitions, documentary reports or video-magazines, children and young people have the opportunity to articulate their ideas using different media and can thus spread them beyond the school environment. They realize then that the reality presented in the media is subjectively shaped and oriented under the influence of (corporate) interests. Practical and creative media work is especially suitable for encouraging different forms of collaborative 
learning. By working in groups students learn how media products are generated and how individuals are directed to co-operate with others /17/. By sharing their roles and different jobs they reveal their preferences, abilities and skills.

Based on the above mentioned, the development of digital competence should be integrated into the system of higher education, and be continually developeded through formal and informal education programs. It should most certainly be the imperative of permanent training of teachers and associates working at higher educational institutions. Media education can be successful only when society and politics together create a framework that lead to the media environment suitable for children and young people. Media education requires the responsibility of all who are involved in the teaching process. Social and cultural work with children and young people provides the possibility to expand cultural opportunities. Many activities in this area, as well as voluntary participation, offer good opportunities for developing the students' creativity. In order to live with the media in a modern technology-globalization society, all students need to acquire a general media competence $/ \mathbf{1 3} /$.

\section{Notes}

/1/ Gobo (2012). Razvoj digitalne kompetencije u obrazovanju- doktorski rad.; Zagreb.

/2/ Tayner, K. (1998). Literacy in a Digital World: Teaching and Learning in the Age of Information. MPublishing, University of Michigan Library.

/3/ Tolić, M. (2015). Digital society and Learner Identity: Saarbrucken. Academic Publishing $\mathrm{GmbH} \& \mathrm{C}$.

/4/ Aufenanger, S. (2004). Medienpädagogik und Medienkompetenz: Eine Bestandsaufnahme. In: Enquete-Kommission 'Zukunft der Medien in Wirtschaft und Gesellschaft. Deutschlands Weg in die Informationsgesellschaft'. Deutscher Bundestag (Hrsg.), Medienkompetenz im Informationszeitalter. Bonn, 15-22.

/5/ Baacke, D.; Ferchhoff, W.; Vollbrecht, R. (1997). Kinder und Jugendliche in medialen Welten und Netzen. In: Fritz, J.; Fehr, W. (Hrsg.), Handbuch
Medien: Computerspiele. Theorie, Forschung, Praxis. Bonn: Bundeszentrale für politische Bildung, 31-57.

/6/ Young, R. E.; Becker, A. L.; Pike, K. L. (1970). Rhetoric: Discovery and Change. New York-Chicago-San Francisco-Atlanta: Harcourt, Brace \& World, Inc.

/7/ Terhart, E. (2001). Metode poučavanja i učenja: uvod $u$ probleme metodičke organizacije poučavanja $i$ učenja. Zagreb: Educa.

/8/ Miliša, Z., Tolić, M., Vertovšek, N. (2008). Mediji i mladi. Zagreb: Sveučilišna knjižara

19/ Prensky, M. (2001). Digital Natives, Digital Immigrants. On the Horizon. MCB University Press, Vol. 9 No. 5, October

/10/ Bindé, J. et al. (2007). UNESCO-ovo svjetsko izvješće: prema društvima znanja. Zagreb: Educa.

/11/ Moser, H. (2006): Standards für die Medienbildung. Schweizer Erfahrungen mit der Entwicklung von Standards. Computer+Unterricht, 63, 16-18.

112/ Moser, H. (2007). Standards in der Medienbildung. ein Standardmodell aus der Schweiz. Computer+Unterricht, 63, 49-55.

/13/ Spajić-Vrkaš, V. (1999). Jedinstvo u raznolikosti: promicanje ljudskih prava i sloboda odgojem i obrazovanjem. Obrazovanje odraslih: časopis za obrazovanje odraslih i kulturu. 43, 1-4, 11-31.

/14/ Meyer, T. (2003). Mediokracija: medijska kolonijalizacija politike. Politička misao. Zagreb, 31-32.

/15/ Miliša, Z., Tolić, M., Vertovšek, N. (2008). Mediji i mladi. Zagreb: Sveučilišna knjižara

/16/ Mijatović, A. (ur.) (1999). Osnove suvremene pedagogije. Zagreb: Hrvatski pedagoško-književni zbor.

/17/ Moser,H. (2015), Die Medienpädagogik und der zweite Strukturwandel der Öffentlichkeit. In: Heinz Moser et al. (Hrsg.), Jahrbuch Medienpädagogik 7.: Medeien, Pädagogik, Politik. Wiesbaden: VS Verlag für Sozialwissenschaften, 23-50.

\section{Internetski izvori:}

Beitragspflichtiger Hochschulzugang, (2010) http://www.bundesfinanzministerium.de/Content/DE/Standardartikel/Ministerium/Geschaeftsbereich/Wissenschaftlicher_Beirat/Gutachten_und_Stellungnahmen/Ausgewaehlte_Texte/1010121a3002.pdf?_blob=publicationFile\&v 